\title{
極超音速におけるデルタ翼・球頭円柱間の空力干渉流れ場*1 Aerodynamic Interaction between Delta Wing and Hemisphere-Cylinder in Hypersonic Flow
}

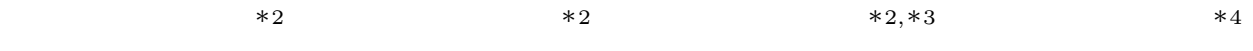 \\ Atsuhiro Nishino, Takafumi Ishikawa, Takumi OKadA and Yoshiaki NAKAmura
}

\begin{abstract}
Key Words : Two Stage To Orbit (TSTO), Hypersonic Flow, Shock/Shock Interaction, Pressure Sensitive Paint (PSP), Temperature Sensitive Paint (TSP), Heat Flux
\end{abstract}

\begin{abstract}
The aerodynamic interaction flow field between a delta wing and a hemisphere-cylinder modeling TSTO (Two Stage To Orbit) in hypersonic flow has been investigated. The paint method for visualization has been improved in order to perform temperature distribution measurements by the Temperature Sensitive Paint (TSP) method, where pressure sensitivity has been reduced by recoating a transparent acrylic paint. The flow field is made complicated by both shock/shock interaction and shock/boundary layer interaction. On the hemisphere-cylinder, the maximum heat flux becomes about 2.7 times as large as the stagnation heat flux in the case of a hemisphere-cylinder alone. On the other hand, the same amount of heat flux as that stagnation value is produced on the delta wing located below the tip of the hemisphere-cylinder.
\end{abstract}

\section{1. は じめに}

宇宙利用時代において, 将来型宇宙輸送システムの開発 が不可欠である ${ }^{1)}$. 将来型宇宙輸送システムに求められる条 件として, 再使用による大幅なコスト削減, 信頼性や経済 性から見た国際競争力, ミッションの柔軟性などが挙げら れる.これらの条件を満たす宇宙輸送システムの代表例と して, 単段式宇宙往還機 (Single Stage To Orbit : SSTO) と，二段式宇宙往還機 (Two Stage To Orbit：TSTO) が ある. 現在は，機体の重量制限やエンジンの性能などによ り, TSTO の研究開発が検討されている .

TSTO は世界各国で研究がなされ, 兴の概念設計が行わ れてきた2).日本においても，機体形状・軌道設計・推進装 置・空力特性などを含む複合的な問題として研究が進めら れている.現在までに提案されてきたTSTOの多くに共通 する点としては, 親機と子機が分離するマッハ数 (分離マッ 八数) が極超音速域に設定されていることである. 产のた め TSTO は, 低速域から高速域までの幅広い速度域を, 親 機と子機が接合された状態で飛行することになる．従って， 空力分野における TSTO 開発における課題として, 樣々な 速度域での空力特性を調べる必要がある．特に, 機体が複 数の構成要素から形成されることによって, 超音速・極超

*1 C 2004 日本航空宇宙学会

平成 14 年 11 月 29 日, 第 39 回日本航空宇宙学会中部・関西支 部合同秋季大会, 平成 15 年 1 月 17 日, 平成 14 年度宇宙輸送シ ンポジウムにおいて発表. 平成 15 年 9 月 22 日原稿受理

*2 名古屋大学大学院

*3 現 三菱重工業 (株)

$* 4$ 名古屋大学航空宇宙工学専攻
音速領域において衝撃波・衝撃波干渉や衝撃波・境界層干 渉といった空力干渉問題が生じる.

これらの空力干渉問題は, 過去に多くの研究がなされて きた、衝撃波・衝撃波干渉問題については, Edney ${ }^{3)} に よ$ り, 兴の干渉パターンが分類されている.また，衝撃波・境 界層干渉においては, 層流と乱流境界層の両方について研 究がなされてきた ${ }^{4 \sim 6)}$. これらの空力干渉は通常，局所的な 圧力および空力加熱率の増加をもたらす．特に，極超音速 領域において空力干渉による空力加熱率の増加を定性的あ るいは定量的に把握することは, 機体表面材料を決定する 上で重要である。しかし，このような空力干渉が生じる可 能性のある TSTO に関する研究においては, 2 物体の位置 関係などパラメータが多く, 詳細な流れ場を解析した研究 は少ない，また，実験パラメータが多くなるので, 効率の 良い実験方法が要求される。

本研究では, 親機を模擬したデルタ翼と子機を模擬した 球頭円柱により構成される TSTO 模型を用い，極超音速域 $\left(M_{\infty}=8.1\right)$ で風洞試験を行い，2物体間の空力干涉流れ 場を実験的に調べ，弚の詳細を明らかにする．

最近，流体現象を調べる場合に理想とされる「場」と しての計測を可能とした，感圧塗料 (Pressure Sensitive Paint : PSP) 計測法7,8) や感温塗料 (Temperature Sensitive Paint : TSP) 計測法9,10) が, 光学系システムの急速 な発達に伴い, 盛んに研究されている.本研究においても， 空力干渉流れ場全体を把握するために，これらの計測方法 を用いた。

一般に，TSP 計測法では，感温物質をバインダーに混合 して塗装する方法が用いられている。しかし, 本研究での 
衝撃風洞のように，通風時間が非常に短い風洞では，干渉 領域の温度測定を行う場合には, 圧力の変化が大きく, 温 度変化を測定することが困難である. 弚こで, 本研究では, 衝撃風洞試験での，TSP 計測法における塗装方法の改良も 行う.

\section{2. 実 験 方 法}

2.1 風洞および測定項目 本研究では, 名古屋大学航空 宇宙工学専攻の衝撃風洞を使用した.気流マッ八数は $M_{\infty}=$ 8.1 , 吹き出し口径 $350 \mathrm{~mm}$, 有効測定時間は $50 \mathrm{msec}$ であ る.実験内容は，1) シュリーレン法による流れの可視化， 2) 感圧塗料 (Pressure Sensitive Paint : PSP) 計測法と, 3) 感温塗料 (Temperature Sensitive Paint : TSP) 計測 法による流れの可視化, さらに，4）空力干渉領域での圧力 および加熱率分布の測定である.

2.2 実験模型 第 1 図に実験模型の概要を示す. 実験 模型は, 親機を模擬した後退角 $\Lambda=75 \mathrm{deg}$, 全長 $L=$ $200 \mathrm{~mm}$ の前縁が鋭く尖った形状のデルタ翼と，子機を模 擬した直径 $D=23 \mathrm{~mm}$ の球頭円柱の 2 物体から構成されて いる.翼弦長 $L$ に基づくレイノルズ数は, $R e_{L}=1.3 \times 10^{6}$ である.デルタ翼と球頭柱間の隙間は $h=5 \mathrm{~mm}$ で, 球頭 円柱先端位置は，デルタ翼頂点より $130 \mathrm{~mm}$ 後方にある。 また， $x$ 軸をデルタ翼頂点から主流方向にとり，さらに， $\phi$ を球頭円柱の子午面 (デルタ翼に垂直) 内で, 球頭円柱中 心軸からの角度 (デルタ翼と反対側を正) とする．

2.3 感圧塗料( PSP: Pressure Sensitive Paint) 計測法 近年, 光学系システムの進歩に伴い, 感圧塗料 (Pressure Sensitive Paint : PSP) 計測法が発展してきた . 本研究では，流れ場を把握する上で，「場」の情報を得るこ とができるこの計測法を用い, TSTO 模型の空力干渉場を 調べる.PSP 計測法を用いる場合, 本研究のような通風時 間の短い衝撃風洞では, 弚の応答性が重要となる. 高速応 答性に関する研究では, アルミ酸化皮膜に感圧物質を吸着 させる塗装方法か開発されている7)．しかし，この塗装方法 は, 母材がアルミに限定される. 弚こで, 本研究では, 栗

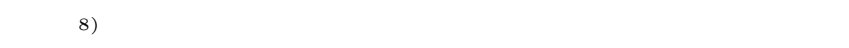
使用が可能でかつ扱いやすく，粘着材によって感圧物質を 模型表面にむき出しの状態で固定する塗装方法を採用した .

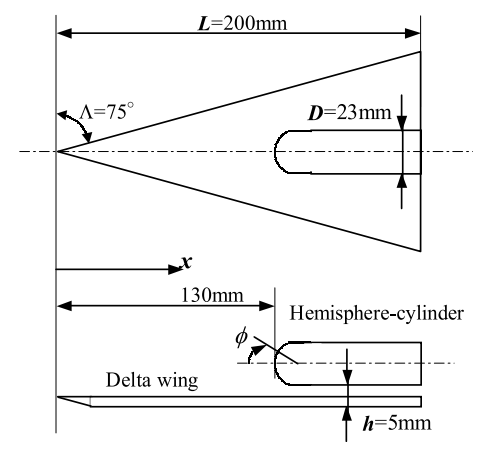

第 1 図 実験模型概要図
2.4 感温塗料( TSP: Temperature Sensitive Paint）計測法 極超音速て飛行する物体については, 空 力加熱が重要な課題となる. 特に空力干渉領域では, 局所 的に圧力・温度ともに非常に高くなる. 本研究では, 感温 塗料計測法を用いて，模型全体の温度分布を調べた．TSP 計測法は, 感温物質の温度消光現象を利用して温度を計測 する方法である . 温度消光現象とは, 温度の上昇による振 動や衝突によって励起分子が無輻射で基底状態に落ち，光 の結果蛍光が弱くなる現象のことである . 一般に温度消光 は , 感温物質か酸素による影響を受けない場合には次の経 験式で表すことができる ${ }^{10)}$.

$$
\frac{T}{T_{\mathrm{ref}}}=A \frac{I}{I_{\mathrm{ref}}}+B
$$

ここで, 添字の ref は基準状態を表している．

第 2 図に, 本研究で改良を行った TSP の塗装方法の概 要を示す. 本研究では, 感温物質として Rhodamine-B を, バインダーとして PMMA を使用した . Rhodamine-B は， 励起波長帯 $(460 \sim 590 \mathrm{~nm})$ と発光波長帯 (550 590 nm) が ともに可視光域の波長帯であり, 比較的圧力感度が小さいと いう特徵がある ${ }^{9)}$. 感温塗料は，まずアセトン $(200 \mathrm{ml})$ に PMMA $(5 \mathrm{~g})$ を溶かし, 弚の後 Rhodamine-B (15 mg) を溶かして作製する．この塗料を，エアスプレで模型表面 に塗装する.塗装方法としては, まず温度変化がなるべく 大きくなるようにウレタン樹脂で模型表面をコーティング し, 光の上に感温塗料を塗装する . また，本研究で対象と する流れ場は空力干渉領域であり，光こでは大きな圧力変 化を伴う.従って, 圧力変化の影響による測定誤差を低減さ せるため,つまり，酸素との接触をより少なくするために， 上記の塗装面に透明なアクリル系塗料を上塗りした . 感温 塗料とアクリル系塗料の層を合わせた厚さは, 15〜20 $\mu \mathrm{m}$ である

2.5 加熱率 本研究では, 空力加熱率計測に白金薄膜 ゲージと同軸熱電対 (ミューラー社製 Coaxial Thermocouple MCT/MCTB) を使用した .

加熱率は以下の方法で算出した ${ }^{11)}$. 半無限遠物体におけ る物体表面に垂直方向の 1 次元 ( $x$ 方向) 熱伝導方程式は,

$$
\frac{\partial T}{\partial t}=\frac{k}{\rho c} \frac{\partial^{2} T}{\partial x^{2}}
$$

で表される.ただし， $x=0$ と $x=\infty$ での境界条件は，

$$
\begin{array}{ll}
q=-k \frac{\partial T}{\partial x} & (x=0) \\
T=0 & (x=\infty)
\end{array}
$$

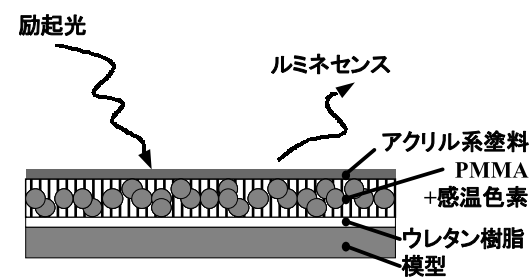

第 2 図 TSP 塗装面の概要図 
である．時間 $t$ での物体表面温度は，式 $(2)$ より，

$$
T=\frac{1}{\sqrt{\pi} \sqrt{\rho c k}} \int_{0}^{t} \frac{q(\tau)}{(t-\tau)^{1 / 2}} \mathrm{~d} \tau
$$

となる . 従って, 式 $(3)$ より加熱率 $q(t)$ は,

$$
q(t)=\sqrt{\frac{\rho c k}{\pi}}\left[\frac{T(t)}{\sqrt{t}}+\frac{1}{2} \int \frac{T(t)-T(\tau)}{(t-\tau)^{3 / 2}} \mathrm{~d} \tau\right]
$$

となる . しかし , 式 (4) は, $t=\tau$ において分母分子が 0 の不定形となるため，積分することができない．乥こで， Cook ら ${ }^{12)}$ に従い, $T(\tau)$ を piecewise linear function で 近似する. 兴の結果, 加熱率 $q(t)$ は,

$$
q(t)=2 \sqrt{\frac{\rho c k}{\pi}} \sum_{i=1}^{m} \frac{T\left(t_{i}\right)-T\left(t_{i-1}\right)}{\left(t_{m}-t_{i}\right)^{1 / 2}+\left(t_{m}-t_{i-1}\right)^{1 / 2}}
$$

と表せる. 本研究では, 式 $(5)$ より $q(t)$ を算出し, 風洞 総圧が $3.9 \mathrm{MPa}$ になった状態を基準として, 兴の時刻から $10 \mathrm{msec}$ 間のデータを平均し，加熱率 $q$ を求めた .なお， 圧力変換器による圧力測定においても同じ時間内での平均 值を圧力とした .

\section{3. 結果と考察}

3.1 シュリーレン法による流れの可視化 第 3 図にシュ リーレン法による流れの可視化を示す. 球頭円柱前方で生 じた弓形衝撃波と, デルタ翼面上から発生した斜め衝撃波 との衝撃波・衝撃波干渉が, 球頭円柱中心軸上方に見られ る.この干渉の原因となる斜め衝撃波は, 弓形衝撃波がデ

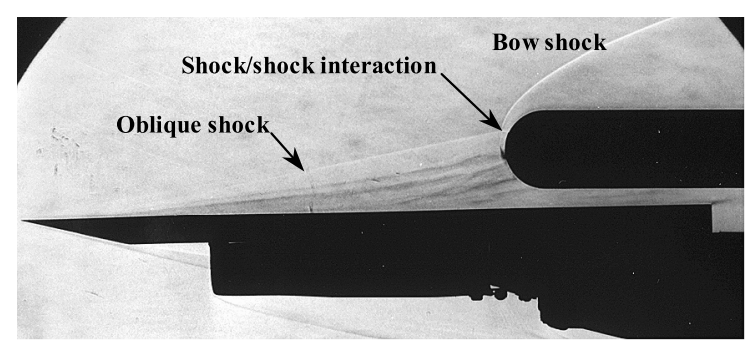

(a) 全体図

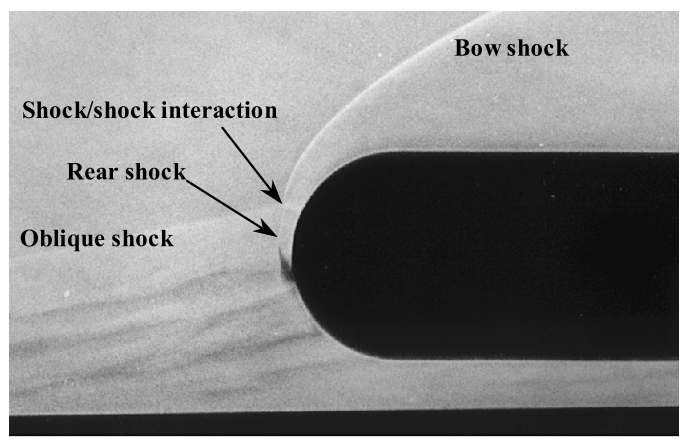

(b) 球頭円柱拡大図

第 3 図 シュリーレン法による流れの可視化
ルタ翼面上の境界層付近に達することにより生じる局所的 な圧力上昇の影響が , 境界層内の亜音速領域を上流に伝播 し，はく離することによって形成される．また，第 3 図 (b) より，斜め衝撃波と弓形衝撃波の干渉により，リア衝撃波 も生じている ${ }^{13)}$.このリア衝撃波は, 弓形衝撃波に比べて より球頭円柱の近くに形成されている.

また，第 3 図 (a) を見ると，はく離点がデルタ翼頂点付 近に位置している．今までの研究に基づけば，衝撃波が境 界層に入射する場合, 弚のはく離点の位置は, 境界層が乱

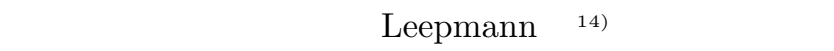
離点の位置は，層流の方がより上流側に移動し，層流の場 合は境界層厚さの約 50 倍のオーダー, 乱流の場合は約 5 倍 のオーダーである. 本研究では, シュリーレン写真よりそ のはく離点の距離を測定したところ, 球頭円柱先端位置よ り約 $100 \mathrm{~mm}$ 程度前方に位置している. 本実験条件におけ る境界層厚さを，

$$
\frac{\delta}{x} \propto \frac{M_{\infty}^{2}}{\sqrt{R e}}
$$

の関係式 ${ }^{15)}$ により見積もると，球頭円柱先端位置における 境界層厚さは数 $m m$ のオーダーとなる .このことより，本 研究では, 衝撃波と層流境界層干渉であると考えられる .

第 4 図に TSTO 模型周りの流れ場の概要を示す. 球頭円 柱前方においてはく離泡が形成され，光のすぐ上に境界層 はく離によるはく離せん断層が存在していると考えられる

3.2 PSP, TSP 計測法による空力干渉流れ場の可視化 TSP 計測法を 2 物体空力干渉流れ場に適用する前に , 塗装 方法の違いによる圧力変化の輝度変化への影響について調 ベた．炎の結果を第 5 図に示す.ここでは，1) PMMAに Rhodamine-B を混合させて塗装した場合と，2) さらに光 の塗装面にアクリル系塗料を上塗りした場合を比較してい る. 前者は圧力変化による輝度の変化が見られるが , 後者 はほとんど変化がない．これより，アクリル系塗料を上塗 りすることで, 感温色素の圧力感度を低減できることが分 かる .

第 6 図にPSP 計測法によるデルタ翼面上およひ球頭円柱 先端部における圧力分布を，第 7 図にTSP 計測法から得ら れた光れ光れの温度分布を示す．第 6 図 (a) より, 球頭円 柱下部のデルタ翼面上において, 比較的大きな圧力増加領 域が存在している。また，第 6 図 (b) を見ると，球頭円柱

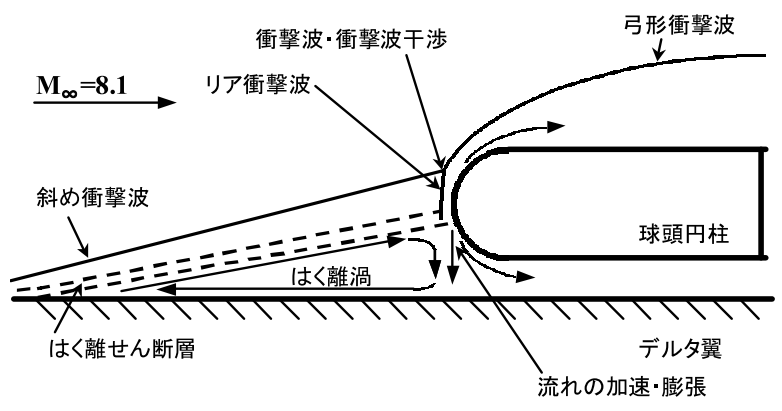

第 4 図 TSTO 模型周りの流れ場の概要 


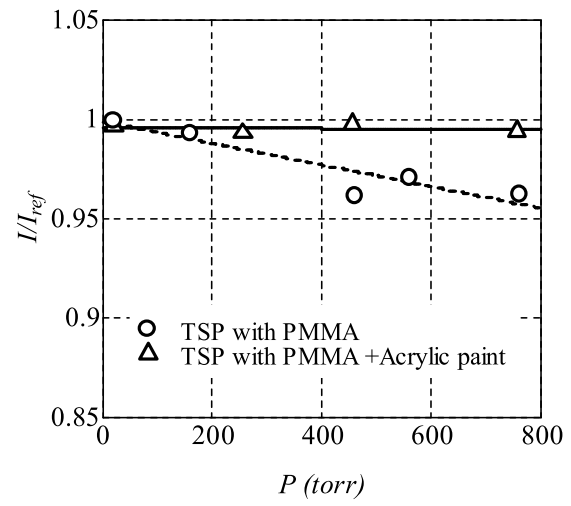

第 5 図＼cjkstart感温塗料の圧力变化による輝度变化

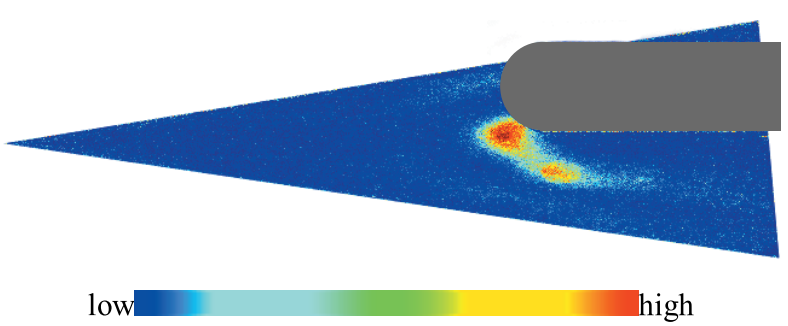

(a) デルタ翼

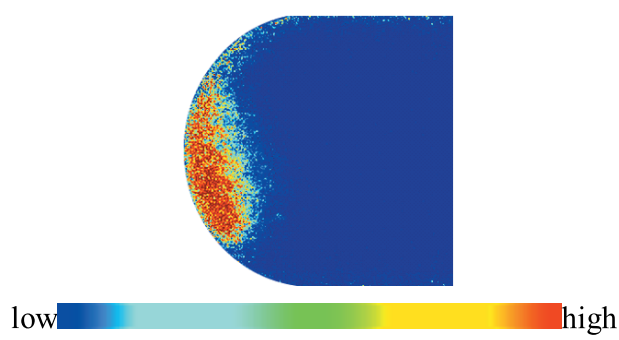

(b) 球頭円柱

第 6 図 PSP 計測法による圧力分布

先端部において, 上下方向に非対称な圧力の増加領域が存 在している .この圧力分布より, 斜め衝撃波はデルタ翼面 上において半円錐状の形状をしていると考えられる.これ らの圧力分布より，斜め衝撃波と弓形衝撃波の干渉によっ て球頭円柱前方に生じたリア衝撃波の影響により，球頭円 柱先端部において高圧領域が形成される．光の高圧領域か ら，デルタ翼側の低圧領域に向かって流れか加速・膨張す る. 并れが, デルタ翼面上に衝突するために, 球頭円柱先 端位置付近におけるデルタ翼面上で，高圧領域が形成され ると考えられる .

第 7 図 (a) は , デルタ翼面上をウレタン樹脂でコーティン グし，Rhodamine-B と PMMA を混合して作製した感温塗 料を塗装した場合の温度分布の結果であり，第 7 图 (b) は， さらに关の塗装面に透明なアクリル系塗料を塗装した場合の 結果である . 両者とも，球頭円柱下部において温度の高い領 域が示されている.第 5 図に示したように，Rhodamine-B は圧力変化の影響を被るため, 第 7 图 (a)の結果には温度 変化の他に，圧力による輝度の変化も含まれている．また， 全体にノイズが目立ち, 輝度の変化が不鮮明となっている。

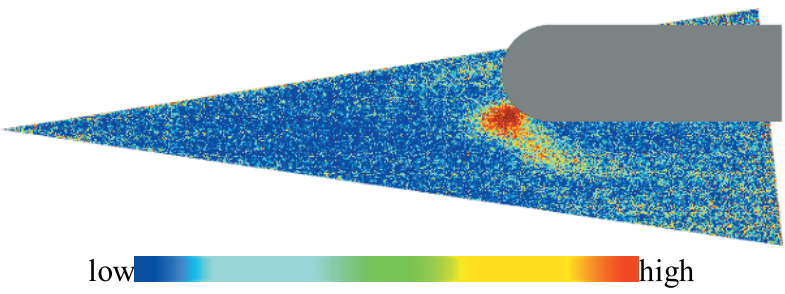

(a) デルタ翼 $(\mathrm{TSP}+\mathrm{PMMA})$

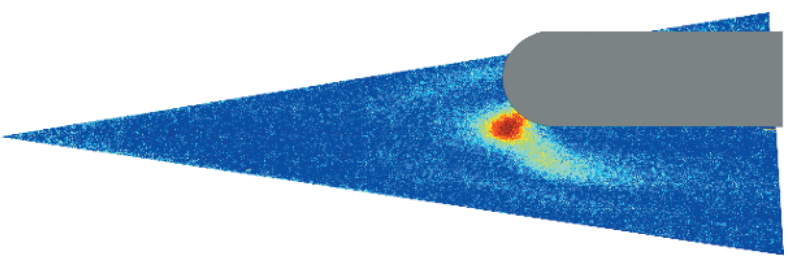

low high

(b) デルタ翼 (TSP+PMMA with Acrylic paint)
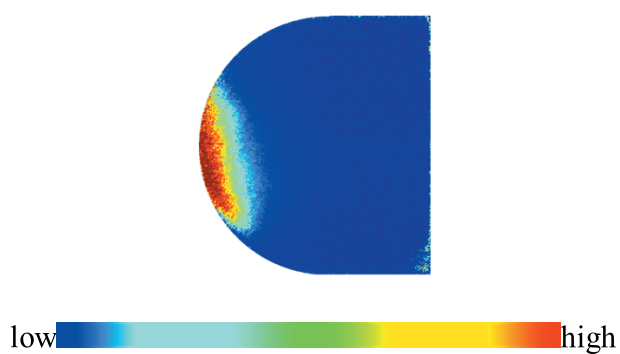

(c) 球頭円柱 (TSP+PMMA with Acrylic paint) 第 7 図 TSP 計測法による温度分布

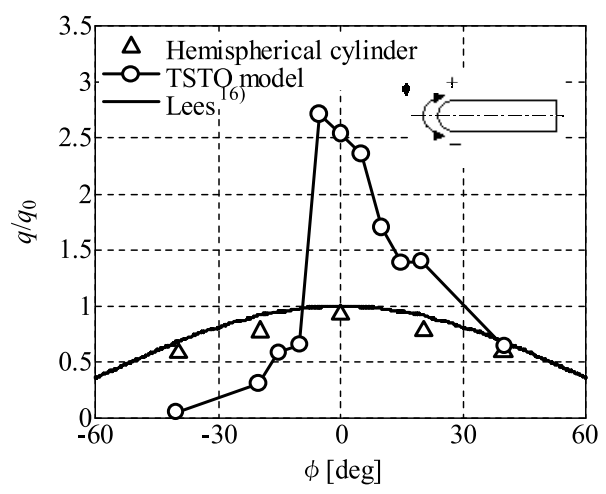

第 8 図 球頭円柱表面の加熱率分布

一方，第 7 図 (b) では, 透明なアクリル系塗料を塗装した ことにより圧力感度が押さえられているため, 温度による 輝度の变化がより鮮明に現れている.また, 第 7 图 (a)に 比べてノイズが少なく，より良く干渉領域の変化を捉えて いる。

第 7 図 (c)の，球頭円柱先端部表面における温度分布に関 しては，上下非対称な゙温度増加領域が見られる．以上述へ た，PSP，TSP 計測法による可視化結果から, 空力干渉領 域における圧力と温度は類似した分布となることが分かる．

3.3 球頭円柱先端部での加熱率分布 第 8 図に, 球頭 円柱先端部での加熱率の測定結果を示す . 図には, 球頭円 柱のみで測定した結果と，2物体空力干渉流れ場の場合，さ 
らに比較のために式 (7) で与えられる, Lees ${ }^{16)}$ による球頭 円柱のみの場合の関係式より導いた加熱率分布を示す . こ こで，添え字 0 は澱点での条件を表す．また，Lees の分布 において, 澱点での加熱率の値 $q_{0}$ は, 球頭円柱のみで測 定した澱点での加熱率の值を用いている.

$$
\frac{\dot{q}}{\dot{q}_{0}}=\frac{\frac{1}{2} \phi \sin \phi\left[\cos ^{2} \phi+\left(1 / \gamma_{\infty} M_{\infty}^{2}\right) \sin ^{2} \phi\right]}{\left\{\int_{0}^{\phi} \phi \sin ^{2} \phi\left[\cos ^{2} \phi+\left(1 / \gamma_{\infty} M_{\infty}^{2}\right) \sin ^{2} \phi\right] \mathrm{d} \phi\right\}^{\frac{1}{2}}}
$$

球頭円柱のみで測定した結果と Lees の分布は, ほぼ一致 している .このときの，澱点における加熱率は約 $25 \mathrm{~W} / \mathrm{cm}^{2}$ である.一方, Kaneko ら ${ }^{17)}$ による名古屋大学航空宇宙工 学専攻の衝撃風洞に対する CFD 結果では, 本実験と同じ時 刻における風洞総温は約 $850 \mathrm{~K}$ となっており，これを使っ て Fay ら ${ }^{18)}$ による関係式，

$$
\begin{aligned}
q_{w}= & 0.76 \operatorname{Pr}^{-0.6}\left(\rho_{e} \mu_{e}\right)^{0.4}\left(\rho_{w} \mu_{w}\right)^{0.1} \\
& \times \sqrt{\left(\frac{\mathrm{d} u_{e}}{\mathrm{~d} x}\right)_{s}}\left(h_{0 e}-h_{w}\right) B
\end{aligned}
$$

を用いる. $B$ は化学反応に関する量であり，

$$
B=1+\left(L e_{w}^{a}-1\right) \frac{h_{D}}{h_{e}}
$$

となる.ここでは簡単のため化学反応を伴わないとして澱 点加熱率を算出すると, $26.8 \mathrm{~W} / \mathrm{cm}^{2}$ となる .この值は, 実 験值に近く，本測定結果の妥当性を示している.

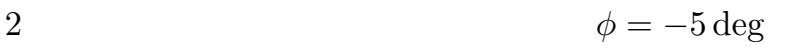

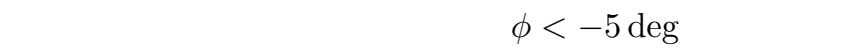
柱のみの場合に比へて全体に低い值となり， $\phi>-5 \operatorname{deg} て ゙$ は高い值となる .これは, 前述の PSP , TSP 計測法におい て得られた結果とも良く一致している. $-5<\phi<20 \mathrm{deg}$ では，第 3 図 (b)のシュリーレン写真を見ると，斜め衝撃 波と弓形衝撃波の干渉によってリア衝撃波が生じている領 域である.この領域では, リア衝撃波が弓形衝撃波よりも 球頭円柱に近い位置で形成されており，加熱率か増加する と考えられる.特に，最も加熱率の高い $\phi=-5 \operatorname{deg} て ゙ は ，$ 球頭円柱単独の場合の澱点加熱率と比べて約 2.7 倍となる これは,境界層はく離により生じたはく離せん断層の影響で

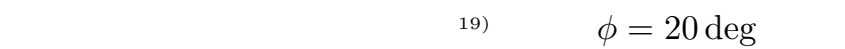
弓形衝撃波と斜め衝撃波との衝撃波・衝撃波干渉による局 所的な加熱率の増加が見られる.一方， $-10<\phi<-5 \mathrm{deg}$ の領域で加熱率が急激に減少している原因は, 第 6 図 (b) で示した球頭円柱先端部の高圧領域から，はく離せん断層 下方 (デルタ翼側) の一樣流の影響が直接無い領域に対し て，流れがジェットのように加速・膨張するためであると 考えられる。

3.4 デルタ翼面上の圧力および加熱率分布 第 9 図に， デルタ翼対称軸上の空力干渉領域における圧力および加熱 率の測定結果を示す . 圧力と加熱率はほぼ相似な分布となっ

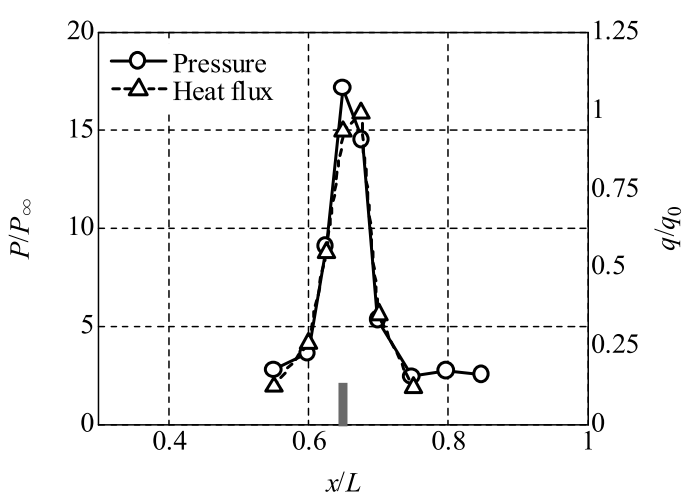

第 9 図 デルタ翼面上の圧力および加熱率分布

ている、本研究では, デルタ翼面上において弓形衝撃波と 境界層との干渉が生じてはく離泡が形成される .この干渉 における圧力と加熱率の相似な分布に関しては, 次式のよ うな関係が示されている15).

$$
q_{w} \propto \sqrt{p_{e}}
$$

ただし，この関係は層流境界層のみに適用される．

第 9 图より球頭円柱先端位置 $(x / L=0.65)$ 付近におい て , 圧力 , 加熱率ともに急激に上昇している. 弚のピーク 值は, 圧力て静圧の約 17 倍, 加熱率で澱点加熱率と同程度 の值である . 圧力および加熱率は， $x / L<0.6$ では，下流 方向に徐々に上昇し, $0.6<x / L<0.65$ では, 急激に増加 し, $0.65<x / L<0.75$ では, 両者とも急激に減少に転じ ている、これは, 球頭円柱肩より生じた膨張波がデルタ翼 に当たり，圧力か減少し，光の結果，加熱率も減少すると 考えられる . 兴の後の領域では, 圧力はほほ横ばいである.

以上の結果より，本研究で用いた TSTO 模型における流 れ場は, 衝撃波・境界層干渉と, 衝撃波・衝撃波干渉の両方 の空力干渉が混在する複雑な流れ場である (第 4 図参照) . 実際のTSTO 開発においては, 子機先側だけでなく, 親機 側にも十分な熱防御対策が必要になると考えられる.

$$
\text { 4. ま と め }
$$

本研究では, TSTO を模擬した親機 (デルタ翼) と子機 (球頭円柱) の 2 物体間の空力干渉流れ場について衝撃風洞 を使って実験的に調べた .また，TSP 計測法の塗装方法を 改良することにより，干渉領域における温度分布測定が可 能となった .さらに，PSP，TSP 計測法と，各センサでの 点計測を併用することで, 実験効率を向上させることがで きた 。

TSTO 模型を用いた 2 物体間の空力干渉流れ場では, 球 頭円柱による弓形衝撃波とデルタ翼面上の境界層との衝撃 波・境界層干渉と, 境界層のはく離による斜め衝撃波（はく 離衝撃波) と弓形衝撃波との衝撃波・衝撃波干渉との 2 種 類の空力干渉が生じる複雑な流れ場が観察された．球頭円 柱表面では, 斜め衝撃波と弓形衝撃波の干渉によるリア衝 撃波によって圧力および加熱率が増加する . 特に , はく離 せん断層の影響により, 最大加熱率は球頭円柱単独の場合 
に比べて約 2.7 倍に達した．また，デルタ翼面上では，圧 力と加熱率は，球頭円柱先端下方において最大となり，光 こでの最大加熱率は，澱点加熱率とほぼ同程度である．

\section{参 考 文 献}

1) 棚次亘弘: 宇宙 3 機関における再使用型宇宙輸送システムの研究 開発の状況，第 46 回宇宙科学技術連合講演会講演集, 2002, pp. $561-565$.

2) Dulepov, N. P., Lanshin, A. I., Sokolova, O. V. and Tjurikov, E. V.: Propulsion Systems for TSTO Airplane-Accelerators of Different Types, AIAA/NAL-NASDA-ISAS International Space Planes and Hypersonic Systems and Technologies Conference 10th, AIAA Paper 2001-1914, 2001.

3) Edney, B.: Anomalous Heat Transfer and Pressure Distributions on Blunt Bodies at Hypersonic Speed in the Presence of an Impinging Shock, Aeronautical Research Institute of Sweden, Report 115, Stockholm, 1968.

4) Green, J. E.: Interactions between Shock Waves and Turbulent Boundary Layers, Prog. Aerospace Sci., 11 (1970), pp. 235-340.

5) Settles, G. S. and Dolling, D. S.: Sweep Shock Wave Boundary Layer Interaction, AIAA Progress in Astronautics and Aeronautics 104, Tactical Missile Aerodynamics, 1986, pp. 297-379.

6) Stollery, J. L.: Glancing Shock-Boundary Layer Interactions, AGARD FDP VKI Special Course on Three-Dimensional Supersonic and Hypersonic Flows Including Separation, 1989.

7) 浅井圭介: 感圧塗料による圧力分布の計測技術, 可視化情報, 18 (1998), pp. 97-103.

8) 栗田 充, 岡田拓己, 中村佳朗 : 衝撃風洞における感圧塗料計測 法について，日本航空宇宙学会論文集，51 (2003), pp. 10-16.
9）飯島由美, 神田 宏, 国益徹也, 浅井圭介 : 各種の感温塗料のサ ンプル特性試験，第 58 回・第 59 回風洞研究会議論文集, 1997, pp. 187-193.

10) 浅井圭介, 神田 宏, 飯島由美, 国益徹也, 河野 敬：感圧塗料 と感温塗料一低温風洞への応用を中心に, 航空宇宙技術研究所特 別資料，SP42, 1999, pp. 25-30.

11) Schults, D. L. and Jones, T. V.: Heat-Transfer Measurements in Short-Duration Hypersonic Facilities, AGARD-AG165, 1973.

12) Cook, W. J. and Felderman, E. J.: Reduction of Data from Thin Film Heat Transfer Gauges, A Concise Numerical Technique, AIAA J., 4 (1966), pp. 561-562.

13）岩崎地平，村上 哲，本阿弥眞治：鈍頭フィンによる衝撃波/平 板乱流境界層干涉場の非定常圧力変動について, 日本機械学会論 文集 , 64 (1998), pp. 3630-3635.

14) Leepmann, H. W., Roshko, A. and Dhawan, S.: On Reflection of Shock Waves from Boundary Layers, NACA Report 1100, 1952.

15) Anderson, J. D., Jr.: Hypersonic and High Temperature Gas Dynamics, AIAA, Reston, 2000.

16) Lees, L.: Laminar Heat Transfer over Blunt-Nosed Bodies at Hypersonic Flight Speeds, Jet Propul., 26 (1956), pp. 259269.

17) Kaneko, M. and Nakamura, Y.: Effect of Shock Wave/ Boundary Layer Interaction on Reservoir Temperature in Shock Tunnel, 30th AIAA Fluid Dynamics Conference, AIAA Paper 99-3529, 1999.

18) Fay, J. A. and Riddell, R.: Theory of Stagnation Point Heat Transfer in Dissociated Air, J. Aeronaut. Sci., 25 (1958), pp. $73-85$.

19) Van Direst, E. R.: Investigation of Laminar Boundary Layer in Compressible Fluids Using the Crocco Method, NACA TN2597, 1952. 